This is a peer-reviewed, accepted author manuscript of the following research chapter: Borz, G. (Accepted/In press). Old party, new party? How to organise for electoral success across diaspora. PS - Political Science and Politics.

\title{
Old party, new party? How to organise for electoral success across diaspora
}

\begin{abstract}
Traditional ways of party mobilisation are losing ground across diaspora. The recipe for electoral success across expatriates is different from the national recipe of winning elections. A party with more informal organisation, strong digital communication and a relevant party programme that speaks to the needs of diaspora is likely to gain more votes from non-resident citizens.
\end{abstract}

The question of how diasporas vote is important per se, and also raises the issue of how best to stimulate the political participation of non-resident citizens in national and presidential elections but also in referendums. Very few European countries offer special parliamentary seats to diaspora and Romania is one of them. Diaspora votes are counted in a special district (Law 35/2008) which elects 2 senators and 4 deputies to the Romanian Parliament. The election of representatives in a designated constituency for overseas voters provides a strong incentive to participation as voting preferences are not scattered across multiple districts. Furthermore, voting abroad has become increasingly simplified through the adoption of postal voting (Law 208/2015) or voting over 3 days (HG 630/2019). In this context, the question is what type of party manages to attract diaspora votes?

First, I argue that while old parties have the organisational capacity, resources and could benefit from the votes of non-resident citizens, it is actually new parties that succeed the most in attracting those votes. It is not resources that a party needs the most in order to engage with diaspora but an effective on-line communication strategy, less costly than traditional voter mobilization strategies. It is not the structural articulation of the party that matters the most for electoral campaigning and coordination across districts. The ad-hoc informal on-line engagement with diaspora can have an electoral impact considering that the target group is scattered across countries abroad. It is not the age of parties and their experience that impacts greatly on electoral success across diaspora but the main party message.

The Social Democratic Party (PSD) is the most institutionalized post communist party in Romania. It has a high membership and relatively strong electoral support across the country. The party's reputation suffered however, from corruption scandals. Many of its officials have been prosecuted and convicted for corruption charges. The party acknowledges diaspora the most in its statute, but the level of on-line engagement with diaspora is very low (Borz, 2020). Its candidates obtained the lowest number of votes across diaspora at the 2019 European elections. The Liberal Party (PNL), another institutionalized party, managed to reform its statute. For example, PNL added provisions according to which collaborators with the former communist secret service or party members under prosecution for corruption can no longer run for elections. PNL's on-line activity however is more intense than that of PSD. The electoral 
success of PNL across diaspora was visible during presidential elections when in the run-off their candidate opposed the PSD candidate. Union Save Romania Party (USR) established only in 2016, does not have local branches all across the country but was much more successful at connecting with diaspora (BEC, 2019). On-line communication via dedicated webpages, Twitter accounts or Facebook pages were efficiently used but also showed high activity (followers, messages etc). The results were visible especially at the last presidential and European elections when the party received a large percentage of its total votes from diaspora.

Second, I also argue that the link between parties and diaspora is stronger when certain political issues become salient across diaspora and when party-voter congruence on those issues is high. In new democracies institutional and economic development are topical issues but more relevant in recent decades is the fight against corruption as a way towards improving good governance.

In Romania, alongside with improving the economy, living standards, healthcare or welfare conditions, corruption eradication has become a salient issue at home and abroad especially after 2012, when new anti-corruption institutions such as the National Agency against Corruption, were established. The Romanian civil society and media mobilized very well against corruption in various forms and diaspora followed with strong anti-corruption protests organised in Bucharest in 2018 and 2019. Not all parties could respond to anti-corruption voter preferences. PSD, the post-communist successor party could not attract diaspora votes as it had corrupt officials amongst its ranks. PNL reformed its candidate selection rules and many of its members had to resign from official positions due to corruption charges. USR however, has as one of the main goals the fight against corruption. The strong anti-corruption programme coupled with strong on-line communication strategies with party members abroad was the key to success across diaspora.

All in all in contrast to traditional accounts which link institutionalization, organisation, electoral strategies and nation-wide electoral success, for diaspora it is the on-line organisation combined with issue salience and issue congruence that ensures most party success. It is not the old parties that benefit the most from this recipe for success, but new parties which manage to get their message across diaspora. Not the new splinter parties, but the newly established parties with a specific anti-corruption programme.

\section{References}

Law no 35/2008 for the election of the Chamber of Deputies and the Senate, available at https:/www.roaep.ro/legislatie/wp-content/uploads/2013/03/Legea-35.pdf, accessed March 2020.

Law 208/2015 for the election of the Senate and Chamber of Deputies http://www.roaep.ro/legislatie/wp-content/uploads/2015/12/Lege-nr.-208-2015-actulizare-2211-2015.pdf, last accessed 
HG 630/2019 Calendar program for actions necessary during presidential elections, https://www.roaep.ro/legislatie/articole-legislatie/hotararea-guvernului-nr-630-2019-privindaprobarea-programului-calendaristic-pentru-realizarea-actiunilor-necesare-pentru-alegereapresedintelui-romaniei-in-anul-2019/, last accessed March 2020.

Borz, Gabriela (2020) Do parties need diaspora? A case study of Romanian parties' involvement abroad. Parliamentary Affairs forthcoming.

BEC (2019) Central Electoral Bureau https://prezenta.bec.ro/prezidentiale24112019/abroadprecincts, last accessed March 2020. 